AJIE - Asian Journal of Innovation and Entrepreneurship

(e-ISSN: 2477- 0574; p-ISSN: 2477-3824)

Vol. 02, No. 02, May 2017

\title{
PENGARUH PERTUMBUHAN PERUSAHAAN, TOTAL ASSET TURNOVER, RETURN ON INVESTMENT, EARNING PER SHARE TERHADAP HARGA SAHAM (STUDI PERUSAHAAH MANUFAKTUR DI BEI)
}

\author{
Firmansyah, Masril \\ ${ }^{1}$ Sekolah Tinggi Ilmu Ekonomi (STIE) Mahaputra Riau, Pekanbaru, Indonesia \\ Corresponding E-mail: firmansyahimansyah@yahoo.co.id
}

\begin{abstract}
Investors invest funds into the capital market by expecting capital gains or dividends. Although investors expect capital gains or dividends, of course, the condition is not spared with the risks faced by investors. Investors are considering in deciding investment one of the attention of investors in deciding the investment can be known from the stock price of the company to be invested, because The stock price is a reflection of the condition of the company in general. However, there are several factors that can cause stock prices such as company growth, total asset turnover, return on investment, earnings per share.

The objective of this study is to know whether the company's growth has an effect on the stock price in the manufacturing company listed on Indonesia Stock Exchange, secondly to know whether total asset turnover influence to stock price at manufacturing company listed in Indonesian Stock Exchange, third to know Whether the return on invesment affect the stock price at the manufacturing company listed on the Indonesia Stock Exchange, fourth to know whether the earnings per share effect on stock prices at manufacturing companies listed on the Indonesia Stock Exchange, the fifth to find out whether the company growth, total asset turnover, Return on investment and earnings per share affect the stock price at manufacturing companies listed on the Indonesia Stock Exchange.

The results of this study indicate that simultaneously the growth of the company, total asset turnover, return on investment and earnings per share affect the stock price in manufacturing companies in BEI, while the partial variables that affect the stock price is earnings per share.
\end{abstract}

Keywords: Company Growth, Total Asset Turnover, Return on Investment, Earning Per Share and Stock Price

\begin{abstract}
ABSTRAK
Investor menginvestasikan dananya ke dalam pasar modal dengan mengharapkan adanya capital gain ataupun adanya dividen. Meskipun investor mengharapkan capital gain ataupun adanya dividen tentu saja adanya kondisi tersebut tidak luput dengan adanya resiko yang dihadapi para investor.Investor sangat mempertimbangkan dalam memutuskan investasinya salah satu yang menjadi perhatian investor dalam memutuskan investasinya dapat diketahui dari harga saham perusahaan yang akan dilakukan investasi, dikarenakan harga saham merupakan cerminan dari kondisi perusahaan secara umum. Akan tetapi ada beberapa faktor yang dapat menyebabkan harga saham diantaranya pertumbuhan perusahaan, total asset turn over, return on investment, earning per share.

Tujuan yang diharapkan dari penelitian ini pertama untuk mengetahui apakah pertumbuhan perusahaan berpengaruh terhadap harga saham pada perusahaan manufaktur yang terdaftar di Bursa Efek Indonesia, kedua untuk mengetahui apakah total asset turnover berpengaruh terhadap harga saham pada perusahaan manufaktur yang terdaftar di Bursa Efek Indonesia, ketiga untuk mengetahui apakah return on invesment berpengaruh terhadap harga saham pada perusahaan manufaktur yang terdaftar di Bursa Efek Indonesia, keempat untuk mengetahui apakah earning per share berpengaruh terhadap harga saham pada perusahaan manufaktur yang terdaftar di Bursa Efek Indonesia, kelima untuk mengetahui apakah pertumbuhan perusahaan, total asset turnover, return on
\end{abstract}


investment dan earning per share berpengaruh terhadap harga saham pada perusahaan manufaktur yang terdaftar di Bursa Efek Indonesia.

Hasil penelitian ini menunjukkan bahwa secara simultan pertumbuhan perusahaan, total asset turnover, return on investment dan earning per share berpengaruh terhadap harga saham pada perusahaan manufaktur di BEI, sedangkan secara parsial variabel yang berpengaruh terhadap harga saham adalah earning per share.

Keywords: Pertumbuhan Perusahaan, Total Asset Turnover, Return on Invesment, Earning Per Share dan Harga Saham

\section{PENDAHULUAN}

Investor menginvestasikan dananya ke dalam pasar modal dengan mengharapkan adanya capital gain ataupun adanya dividen. Meskipun investor mengharapkan capital gain ataupun adanya dividen tentu saja adanya kondisi tersebut tidak luput dengan adanya resiko yang dihadapi para investor.

Investor sangat mempertimbangkan dalam memutuskan investasinya salah satu yang menjadi perhatian investor dalam memutuskan investasinya dapat diketahui dari harga saham perusahaan yang akan dilakukan investasi, dikarenakan harga saham merupakan cerminan dari kondisi perusahaan secara umum. Akan tetapi ada beberapa faktor yang dapat menyebabkan harga saham diantaranya pertumbuhan perusahaan, total asset turn over, return on investment, earning per share.

Pertumbuhan perusahaan sangat diharapkan oleh beberapa pihak baik pihak yang berasal dari internal maupun pihak yang berasal dari eskternal perusahaan, dengan bertumbuhnya perusahaan diharapkan dapat memberikan naiknya nilai perusahaan di mata para investor, nilai perusahaan biasanya dapat diketahui dari harga saham perusahaan tersebut.

Menurut Syamsudin dalam Tan dkk (2014), Tinggi rendahnya harga saham suatu industry juga dapat disebabkan oleh seberapa efisien penggunaan seluruh aktiva didalam menghasilkan penjualan semakin tinggi rasio total asset turnover berarti semakin efisien penggunaan seluruh aktiva dalam menghasilkan penjualan. Dengan perkataanlain, jumlah asset yang sama dapat memperbesar volume penjualan apabila total assets turnover nya ditingkatkan atau diperbesar. Total asset turnover ini penting bagi para kreditur dan pemilik perusahaan, tetapi lebih penting lagi bagi manajemen perusahaan karena menunjukkan efisien tidaknya penggunaan seluruh aktiva didalam perusahaan.

Peningkatan laba ini mempunyai efek yang positif terhadap kinerja keuangan perusahaan dalam pencapaian tujuan untuk memaksimalkan nilai perusahaan yang akan direspon secara positif oleh investor sehingga permintaan saham perusahaan dapat meningkat dan dapat menaikan harga saham perusahaan. Modigliani-Miller menyatakan bahwa nilai perusahaan akan tergantung hanya pada laba yang diproduksi oleh aktivaaktivanya (Brigham dan Houston, 2006)

Pertumbuhan laba per lembar saham perusahaan akan sangat dipertimbangkan oleh para investor dalam membuat keputusan untuk berinvestasi. Apabila harga saham mencerminkan kapitalisasi dari laba yang diharapkan di masa yang akan datang, maka peningkatan laba akan meningkatkan harga saham dan 
total kapitalisasi pasar (Rachmad dan Sutrisno,2013).

Tujuan yang diharapkan dari penelitian ini pertama untuk mengetahui apakah pertumbuhan perusahaan berpengaruh terhadap harga saham pada perusahaan manufaktur yang terdaftar di Bursa Efek Indonesia, kedua untuk mengetahui apakah total asset turnover berpengaruh terhadap harga saham pada perusahaan manufaktur yang terdaftar di Bursa Efek Indonesia, ketiga untuk mengetahui apakah return on invesment berpengaruh terhadap harga saham pada perusahaan manufaktur yang terdaftar di Bursa Efek Indonesia, keempat untuk mengetar hui apakah earning per share berpengaruh terhadap harga saham pada perusahaan manufaktur yang terdaftar di Bursa Efek Indonesia, kelima untuk mengetahui apakah pertumbuhan perusahaan, total asset turnover, return on investment dan earning per share berpengaruh terhadap harga saham pada perusahaan manufaktur yang terdaftar di Bursa Efek Indonesia.

\section{PERUMUSAN MASALAH}

1. Apakah pertumbuhan perusahaan berpengaruh terhadap harga saham pada perusahaan manufaktur yang terdaftar di Bursa Efek Indonesia?

2. Apakah total asset turnover berpengaruh terhadap harga saham pada perusahaan manufaktur yang terdaftar di Bursa Efek Indonesia?

3. Apakah return on invesment berpengaruh terhadap harga saham pada perusahaan manufaktur yang terdaftar di Bursa Efek Indonesia?

4. Apakah earning per share berpengaruh terhadap harga saham pada perusahaan manufaktur yang terdaftar di Bursa Efek Indonesia?
5. Apakah pertumbuhan perusahaan, total asset turnover, return on investment dan earning per share berpengaruh terhadap harga saham pada perusahaan manufaktur yang terdaftar di Bursa Efek Indonesia?

\section{TUJUAN PENELITIAN}

1. Untuk mengetahui apakah pertumbuhan perusahaan berpengaruh terhadap harga saham pada perusahaan manufaktur yang terdaftar di Bursa Efek Indonesia.

2. Untuk mengetahui apakah total asset turnover berpengaruh terhadap harga saham pada perusahaan manufaktur yang terdaftar di Bursa Efek Indonesia

3. Untuk mengetahui apakah return on invesment berpengaruh terhadap harga saham pada perusahaan manufaktur yang terdaftar di Bursa Efek Indonesia.

4. Untuk mengetahui apakah earning per share berpengaruh terhadap harga saham pada perusahaan manufaktur yang terdaftar di Bursa Efek Indonesia.

5. Untuk mengetahui apakah pertumbuhan perusahaan, total asset turnover, return on investment dan earning per share berpengaruh terhadap harga saham pada perusahaan manufaktur yang terdaftar di Bursa Efek Indonesia.

\section{LANDASAN TEORITIS}

\section{Teori Penelitian}

Pengaruh Pertumbuhan Perusahaan Terhadap Harga Saham

Pertumbuhan perusahaan sangat diharapkan oleh beberapa pihak baik pihak yang berasal dari internal maupun pihak yang berasal dari eskternal perusahaan, dengan bertumbuhnya perusahaan diharapkan dapat memberikan naiknya nilai perusahaan di mata para investor, 
nilai perusahaan biasanya dapat diketahui dari harga saham perusahaan tersebut.

\section{Pengaruh Total Asset Turnover Terhadap Harga Saham}

Menurut Syamsudin dalam Tan dkk (2014), Tinggi rendahnya harga saham suatu industry juga dapat disebabkan oleh seberapa efisien penggunaan seluruh aktiva didalam menghasilkan penjualan semakin tinggi rasio total asset turnover berarti semakin efisien penggunaan seluruh aktiva dalam menghasilkan penjualan. Dengan perkataanlain, jumlah asset yang sama dapat memperbesar volume penjualan apabila total assets turnover nya ditingkatkan atau diperbesar. Total asset turnover ini penting bagi para kreditur dan pemilik perusahaan, tetapi lebih penting lagi bagi manajemen perusahaan karena menunjukkan efisien tidaknya penggunaan seluruh aktiva didalam perusahaan.

\section{Pengaruh Return on Invesment Terhadap Harga Saham}

Peningkatan laba ini mempunyai efek yang positif terhadap kinerja keuangan perusahaan dalam pencapaian tujuan untuk memaksimalkan nilai perusahaan yang akan direspon secara positif oleh investor sehingga permintaan saham perusahaan dapat meningkat dan dapat menaikan harga saham perusahaan. Modigliani-Miller menyatakan bahwa nilai perusahaan akan tergantung hanya pada laba yang diproduksi oleh aktivaaktivanya (Brigham dan Houston, 2006)

\section{Pengaruh Earning Per Share Terhadap Harga Saham}

Menurut Ang, Earning Per Share

(EPS) merupakan perbandingan antara laba bersih setelah pajak pada satu tahun buku dengan jumlah saham yang diterbitkan. EPS menunjukkan seberapa besar keuntungan yang diberikan kepada investor dari setiap lembar saham yang dimilikinya. Secara sederhana EPS menggambarkan jumlah uang yang diperoleh untuk setiap lembar saham. Berdasarkan tingkat keberhasilan perusahaan tersebut, para investor akan memperhatikan pengaruhnya di masa yang akan datang dengan melihat prospek perusahaan yang baik (Rachmad dan Sutrisno, 2013).

Pertumbuhan laba per lembar saham perusahaan akan sangat dipertimbangkan oleh para investor dalam membuat keputusan untuk berinvestasi. Apabila harga saham mencerminkan kapitalisasi dari laba yang diharapkan di masa yang akan datang, maka peningkatan laba akan meningkatkan harga saham dan total kapitalisasi pasar (Rachmad dan Sutrisno,2013).

\section{Penelitian Terdahulu}

Azhari, Sri Mangesti Rahayu dan Zahroh Z.A (2016) melakukan penelitian dengan judul penelitian "Pengaruh ROE, DER, TATO, Dan PER Terhadap Harga Saham Perusahaan Properti Dan Real Estate Yang Go Publik Di Bursa Efek Indonesia". Hasil penelitian menunjukkan bahwa Secara individu, ROE dan PER memiliki pengaruh besar terhadap harga saham. Sedangkan DER dan TATO secara individu tidak berpengaruh besar terhadap harga saham.

Priatinah dan Prabandaru Adhe Kusuma (2012) melakukan penelitian dengan judul penelitian "Pengaruh Return on Invesment (ROI), Earning Per Share (EPS), dan Dividen Per Share (DPS) Terhadap Harga Saham Perusahaan Pertambangan Yang Terdaftar Di Bursa Efek Indonesia (BEI) Periode 2008 - 
2010". Hasil penelitian menunjukkan bahwa Return on Investment secara parsial berpengaruh positif dan signifikan terhadap Harga Saham,hal ini dibuktikan oleh nilai koefisien determinasi ROI sebesar 0,197 dan nilai signifikansit sebesar 0,012, Earning per Share secara parsial berpengaruh positif dan signifikan terhadap Harga Saham, hal ini dibuktikan oleh nilai koefisien determinasi(r2) EPS sebesar 0,463 dan nilai signifikansit sebesar 0,000 Dividen per Share secara parsial berpengaruh positif dan signifikan terhadap Harga Saham, hal ini dibuktikan oleh nilai koefisien determinasi(r2) DPS sebesar 0,787 dan nilai signifikansit sebesar 0,00, Return on Investment, Earningper Share, dan Dividen per Share secara simultanberpengaruh positif dan signifikan terhadap HargaSaham

\section{METODE PENELITIAN}

Jenis penelitian ini mempergunakan pendekatan kuantitatif dan dengan menggunakan data sekunder dari perusahaan manufaktur yang terdaftar di Bursa Efek Indonesia periode 2010 sampai dengan 2014.

Penelitian kuantitatif merupakan suatu metode yang menguji teori-teori yang telah ada sebelumnya dengan cara meneliti hubungan antar variabelnya.

Data yang dipergunakan peneliti pada penelitian ini adalah data sekunder yang terdiri dari laporan keuangan perusahaan manufaktur yang di publikasikan melalui website Bursa Efek Indonesia (http://www.Idx.co.id) tahun 2010 sampai dengan 2014. Data yang diambil pada laporan keuangan perusahaan manufaktur terdiri dari pertumbuhan perusahaan, total asset turnover, return on investment, earning per share dan harga saham perusahaan
Populasi adalah keseluruhan dari karakteristik atau unit hasil pengukuran yang menjadi objek penelitian atau populasi merupakan objek atau subjek yang berada pada suatu wilayah dan memenuhi syarat-syarat tertentu berkaitan dengan masalah penelitian (Suwarno, 2010). Yang akan dijadikan target atau tujuan dari populasi ini adalah perusahaan manufaktur yang terdaftar di Bursa Efek Indonesia yang berjumlah 129 emiten.

Sampel adalah bagian dari populasi yang mempunyai cirri-ciri atau keadaan tertentu yang akan diteliti. Karena tidak semua data dan informasi akan diproses dan tidak semua orang atau benda akan diteliti melainkan cukup dengan menggunakan sampel yang mewakilinya (Suwarno, 2010).

Sedangkan teknik pengambilan sampel yang dilakukan peneliti dengan menggunakan kriteria -kriteria atau pertimbangan-pertimbangan tertentu yaitu:

a. Perusahaan manufaktur yang terdaftar di Bursa Efek Indonesia periode 2010 sampai dengan 2014.

b. Perusahaan manufaktur yang mengalami pertumbuhan perusahaan selama periode 2010 sampai dengan 2014.

c. Perusahaan manufaktur yang mendapatkan keuntungan selama periode 2010 sampai dengan 2014.

Berdasarkan pada kriteria-kriteria pengambilan sampel diatas maka sampel penelitian menjadi 30 sampel atau 30 emiten yang dikalikan dengan tahun pengamatan selama 5 tahun (2010, 2011, 2012, 2013, dan 2014) sehingga menjadi $30 \times 5=150$ observasi pengamatan.

Teknik analisis data pada penelitian ini peneliti menggunakan analisis regresi linier berganda. Yang diketahui untuk mengetahu pengaruh 
variabel bebas terhadap variabel terikat, syarat yang harus dipenuhi oleh peneliti sebelum dilakukannya rergresi linier berganda maka harus terpenuhinya uji asumsi klasik, uji asumsi klasik terdiri dari uji normalitas, uji multikolinieritas, uji heterokedastisitas, dan uji autokorelasi.

Langkah selanjutnya setelah dilakukannya uji asumsi klasik penelitian maka peneliti melakukan uji regresi linier berganda, dengan uji hipotesis yaitu uji simultan dan uji parsial.

\section{HASIL DAN PEMBAHASAN}

Hasil pengujian pada penelitian ini Langkah yang pertama yang dilakukan oleh peneliti yaitu melakukan uji asumsi klasik terdiri dari:

a. Uji Normalitas

1. Scatterplot
Uji normalitas merupakan proses pertama kali untuk mendeteksi ke normalan data. Untuk pendeteksian pada uji normalitas pada penelitian ini peneliti menggunakan scatterplot dan KolmogrovSmirnov (K-S) berikut ini hasil uji normalitas dengan menggunakan scatterplot dan Kolmogrov-Smirnov (K-S) adalah:

a. Uji Normalitas

Uji normalitas pada penelitian ini dengan menggunakan dua cara yaitu pertama dengan menggunakan grafik dan dengan menggunakan KolmogrovSmirnov yaitu:

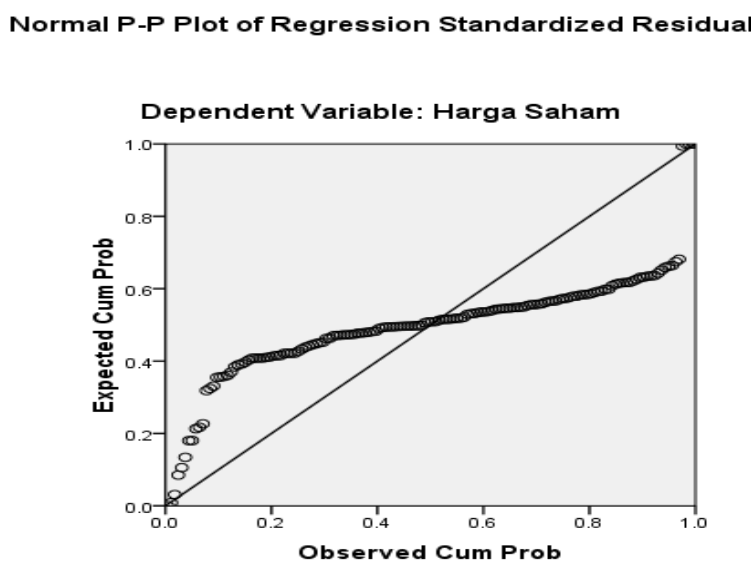

Gambar 2. Uji Normalitas Dengan Sccaterplot

Pada Gambar 2, pada scatterplot menunjukkan data belum terdistribusi normal karena titik-titik terlihat tidak mendekati garis diagonal atau dengan kata lain menjauhi garis diagonal.
2. Kolmogrov-Smirnov (K-S)

Berikut ini hasil uji normalitas dengan menggunakan Kolmogrov-Smirnov adalah sebagai berikut: 
Tabel 3

One Sample Kolmogrov-Smirnov

One-Sample Kolmogorou-Smirnow Test

\begin{tabular}{|ll|r|}
\hline & & $\begin{array}{c}\text { Unstandardiz } \\
\text { ed Residual }\end{array}$ \\
\hline Normal Parameters & & 150 \\
& Mean & .0000000 \\
Most Extreme Differences & Std. Deviation & 6.9293179954 \\
& Absolute & .294 \\
& Positive & .294 \\
Kolmogorov-Smirnov $Z$ & Negative & -.260 \\
Asymp. Sig. (2-tailed) & & 3.600 \\
\hline
\end{tabular}

a. Test distribution is Normal.

Berdasarkan pada Tabel 3. dengan nilai Asymp.Sig (2-tailed) sebesar 0.000 atau nilainya tidak di atas $5 \%$ atau 0.05 , maka dapat dikatakan data tidak terdistribusi dengan normal.

Pada saat uji normalitas dengan menggunakan scatterplot dan dengan menggunakan Kolmogrov-Smirnov (K-S) data tidak terdistribusi normal, maka untuk melakukan pengobatan pada uji normalitas peneliti melakukan logaritma natural, logaritma natural pada penelitian ini dilakukan pada semua variabel bebas dan variabel terikatnya. Berikut ini hasil uji normalitas setelah peneliti melakukan logaritma natural adalah:

\section{Scatterplot}

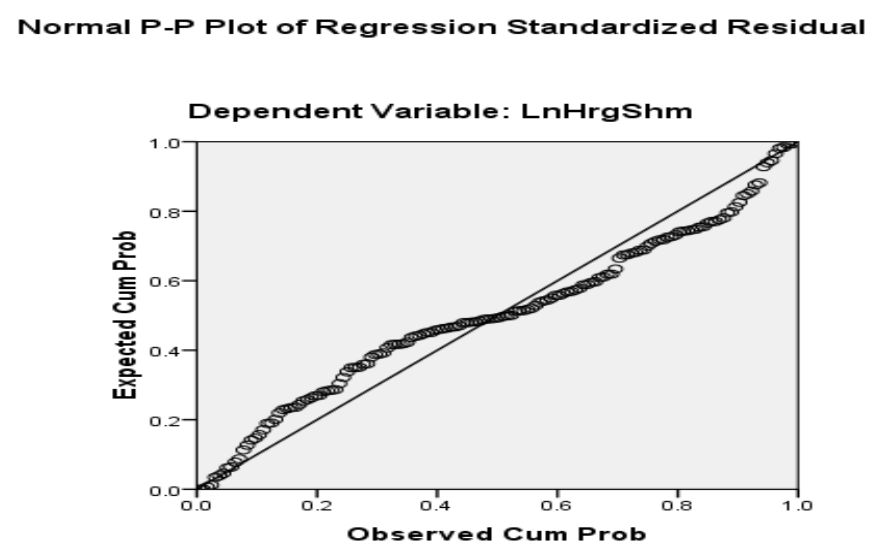

Gambar 3. Uji Normalitas Dengan Sccaterplot Setelah Ln

Berdasarkan pada Gambar 3, bahwa data terdistribusi dengan normal yaitu dengan ditandainya titik-titik mendekati garis diagonal sehingga dapat peneliti simpulkan bahwa data terdistribusi dengan normal. 
2. Kolmogrov-Smirnov (K-S)

\section{Tabel 4}

One Sample Kolmogrov-Smirnov Setelah Ln

One-Sample Kolmogorow-Smirnow Test

\begin{tabular}{|c|c|c|}
\hline & & $\begin{array}{l}\text { Unstandardiz } \\
\text { ed Residual }\end{array}$ \\
\hline $\mathbb{N}$ & & 150 \\
\hline \multirow[t]{2}{*}{ Normal Parameters } & Mean & .0000000 \\
\hline & Std. Deviation & 1.22271912 \\
\hline \multirow[t]{3}{*}{ Most Extreme Differences } & A.bsolute & .097 \\
\hline & Positive & .097 \\
\hline & Negative & -.095 \\
\hline Kolmogorov-Smirnov $Z$ & & 1.183 \\
\hline Asymp. Sig. (2-tailed) & & .122 \\
\hline
\end{tabular}

a. Test distribution is Normal.

Berdasarkan pada Tabel 4, yaitu dengan nilai Asymp.Sig (2-tailed) diatas 0,05 atau diatas $5 \%$ sehingga dapat disimpulkan data terdistrubusi normal. b. Uji Multikolinieritas

Pengujian multikolinieritas peneliti menggunakan variance inflation factor:

Tabel 5

\section{Hasil Uji Multikolinieritas}

Coefficients

\begin{tabular}{|c|c|c|c|c|c|c|c|c|}
\hline \multirow{2}{*}{\multicolumn{2}{|c|}{ Madel }} & \multicolumn{2}{|c|}{ Unstandardized Coefficients } & \multirow{2}{*}{$\begin{array}{c}\begin{array}{c}\text { Standardized } \\
\text { Coefficients }\end{array} \\
\text { Beta }\end{array}$} & \multirow[b]{2}{*}{$\mathrm{t}$} & \multirow[b]{2}{*}{ Siq. } & \multicolumn{2}{|c|}{ Collinearity Statistics } \\
\hline & & B & Std. Error & & & & Tolerance & VIF \\
\hline \multirow[t]{5}{*}{1} & (Constant) & 4.600 & .331 & & 13.903 & .000 & & \\
\hline & LnPrtmbhnPrshn & .043 & .069 & .036 & .625 & .533 & .991 & 1.009 \\
\hline & LnTATO & .208 & .205 & .058 & 1.012 & .313 & .975 & 1.026 \\
\hline & LnROI & .236 & .138 & .120 & 1.717 & .088 & .662 & 1.510 \\
\hline & LnEPS & .582 & .063 & .648 & 9.232 & .000 & .661 & 1.513 \\
\hline
\end{tabular}

a. Dependent Variable: LnHrgShm

Berdasarkan pada uji multikolinieritas nilai tolerance pada variabel pertumbuhan sebesar 0.991, total asset turnover sebesar 0.975 , return on investment sebesar 0.662 , earning per share sebesar 0.661 dan nilai variance inflation factor (VIF) pada variabel pertumbuhan 1.0091, total asset turnover sebesar 1.026, return on investment sebesar 1.510, earning per share sebesar 1.513. Dapat dikatakan tidak terindikasi tidak terjadi multikolinieritas apabila nilai tolerance diatas 0,1 dan nilai VIF dibawah 10. Sedangkan pada hasil penelitian ini nilai tolerance diatas 0,1 dan nilai VIF dibawah 10 sehingga dapat disimpulkan tidak terjadi indikasi gejala multikolinieritas pada penelitian ini.

a. Uji Heterokedastisitas

Pengujian heterokedastisitas dilakukan dengan menggunakan uji scatterplot dan uji Park:

1. Scatterplot 
Berikut ini uji heterokedastisitas penelitian ini adalah: dengan menggunakan scatterplot pada

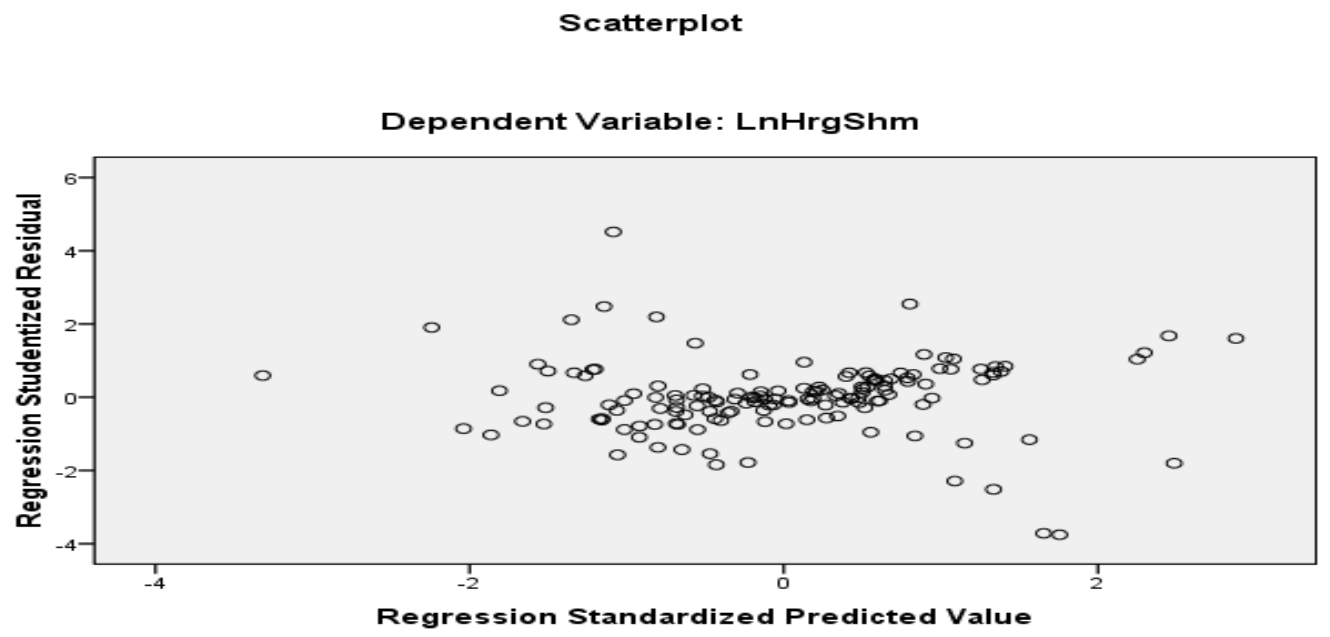

Gambar 3. Scatterplot Uji Heterokedastisitas

Berdasarkan pada Gambar 3, scatterplot menujukkan titik titik terlihat dibawah dan di atas titik 0 , sehingga dapat di ambil kesimpulan tidak terjadi adanya heterokedastistas pada penelitian ini..

a. Uji Park
Uji Park merupakan salah satu uji yang digunakan untuk mendeteksi gejala heterokedastisitas, uji Park dilakukan dengan alasan bahwa jumlah sampel lebih dari 100, sehingga peneliti memperngunakan uji Park dalam mendeteksi gejala heterokedastisitas:

Tabel 6

Uji Park

Coefficients $^{3}$

\begin{tabular}{|c|c|c|c|c|c|c|}
\hline \multirow[b]{2}{*}{ Made } & & \multicolumn{2}{|c|}{ Unstandardized Coefficients } & \multirow{2}{*}{$\begin{array}{c}\begin{array}{c}\text { Standardized } \\
\text { Coefficients }\end{array} \\
\text { Beta }\end{array}$} & \multirow[b]{2}{*}{$t$} & \multirow[b]{2}{*}{ Siq. } \\
\hline & & B & Std. Error & & & \\
\hline \multirow[t]{5}{*}{1} & (Constant) & -1.094 & .501 & & -2.184 & .032 \\
\hline & LnPrtmbhnPrshn & .020 & .111 & .022 & .181 & .857 \\
\hline & LnTATO & .080 & .297 & .034 & .270 & .788 \\
\hline & LnROI & -.110 & .188 & -.094 & -.587 & .559 \\
\hline & LnEPS & .106 & .099 & .174 & 1.078 & .285 \\
\hline
\end{tabular}

a. Dependent Variable: LnU2i

Pada Tabel 6, pada uji Park bahwa nilai sig pada variabel pertumbuhan perusahaan sebesar 0.857 , variabel TATO sebesar 0.788, variabel ROI sebesar 0.559 dan variabel EPS sebesar 0.285 yang semua nilai signifikansi diatas 0,05 atau
5\% sehingga menunjukkan tidak terjadi adanya heterokedastisitas.

c. Uji Autokorelasi

Dalam mendeteksi gejala autokorelasi salah satu cara pendeteksian dilakukan dengan cara menggunakan 
Durbin -Watson (D-W). Berikut ini hasil

Durbin-Watson (DW):

uji autokorelasi dengan menggunakan

Tabel 7

Uji Durbin Watson (Autokorelasi)

Model Summary

\begin{tabular}{|l|c|r|r|r|r|}
\hline $\begin{array}{l}\text { Mode } \\
\perp\end{array}$ & $\mathrm{R}$ & $\mathrm{R}$ Square & $\begin{array}{c}\text { Adjusted R } \\
\text { Sguare }\end{array}$ & $\begin{array}{c}\text { Std. Error of } \\
\text { the Estimate }\end{array}$ & $\begin{array}{c}\text { Durbir- } \\
\text { Wuatson }\end{array}$ \\
\hline 1 & $.727 \mathrm{a}$ & .529 & .516 & 1.23947 & 1.822 \\
\hline
\end{tabular}

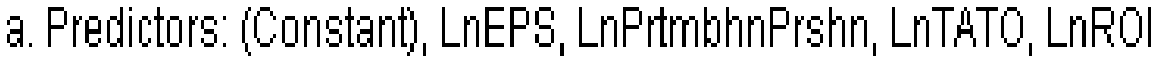

b. Dependent Variable: LrHrgGhm

Berdasarkan pada Tabel 7, nilai DW sebesar 1.822 sehingga menunjukkan tidak adanya gejala autkorelasi karena berada pada posisi -2 sampai dengan 2 .

Setelah dilakukannya langka kedua, peneliti barulah melakukan langka kedua yaitu dengan melakukan regresi linier berganda, regresi linier berganda dengan menguji hipotesis penelitian dengan dasar uji simultan (uji-F) dan uji parsial (uji-t), berikut ini hasil pengujian hipotesis dengan uji simultan (uji-F) dan uji parsial (uji-t) adalah:

\section{1) Uji Simultan (Uji-F)}

Uji simultan ditujukan untuk penguji variabel bebas terhadap variabel terikat secara bersama-sama. Berikut ini hasil pengujian uji simultan pada penelitian ini adalah:

Tabel 8

Uji Simultan

ANOVA ${ }^{\text {b }}$

\begin{tabular}{|ll|r|r|r|r|r|}
\hline Moded & & \multicolumn{1}{c|}{$\begin{array}{c}\text { Sum of } \\
\text { Squares }\end{array}$} & \multicolumn{1}{c|}{ df } & Mean Square & F & Sig. \\
\hline 1 & Regression & 249.738 & 4 & 62.434 & 40.640 & $.000=$ \\
& Residual & 222.761 & 145 & 1.536 & & \\
& Total & 472.499 & 149 & & & \\
\hline
\end{tabular}

a. Predictors: (Constant), LnEPS, LnPrtmbhnPrshn, LnTATO, LnROI

b. Dependent Variable: LnHrgShm

Pada Tabel 8, pada hasil uji simultan bahwa nilai $F_{\text {hit }}$ sebesar 40.640 sedangkan nilai $F_{\text {tab }}$ sebesar 2.43, yang menghasilkan bahwa pertumbuhan perusahaan, total asset turnover, return on investment dan earning per share berpengaruh simultan terhadap harga saham pada perusahaan manufaktur yang terdaftar di Bursa Efek Indonesia periode 2010 sampai dengan 2014.

2) Uji Parsial (Uji-t)

Uji parsial dipergunakan untuk mengetahui pengaruh variabel bebas 
terhadap variabel terikat secara parsial.

parsial adalah:

Berikut ini hasil pengujian hipotesis secara

Tabel 9

Uji Parsial

Coefficients $^{s}$

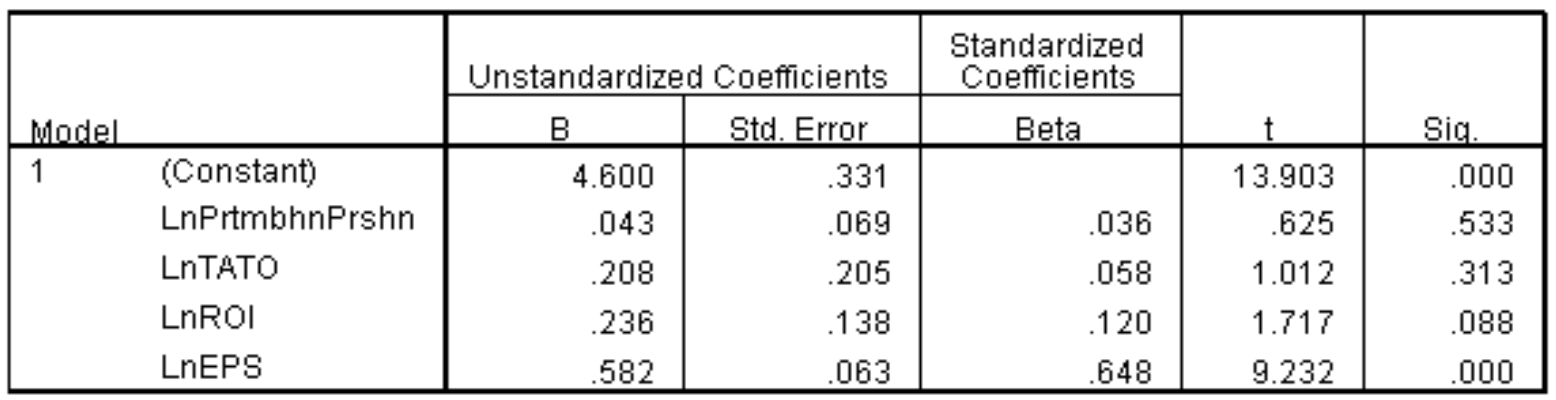

a. Dependent Variable: LnHrgShm

a. Pengaruh

\section{Perusahaan}

Saham

Pertumbuhan perusahaan pada $t_{h i t}$ sebesar 0.625, sedangkan $t_{\text {tab }}$ sebersar 1.65508 atau $t_{\text {hit }}<\mathrm{t}_{\text {tab }}$ dengan kata lain $0.625<1.65508$, yang menunjukkan secara parsial pertumbuhan perusahaan tidak berpengaruh terhadap harga saham dan tidak signifikan pada perusahaan manufaktur yang terdaftar di BEI.

\section{b. Pengaruh Total Asset Turnover Terhadap Harga Saham}

Total asset turnover pada $t_{\text {hit }}$ sebesar 1.012, sedangkan $t_{\text {tab }}$ sebersar 1.65508 atau $\mathrm{t}_{\text {hit }}<\mathrm{t}_{\text {tab }}$ dengan kata lain $1.012<1.65508$, yang menunjukkan secara parsial total asset turnover tidak berpengaruh terhadap harga saham dan tidak signifikan pada perusahaan manufaktur yang terdaftar di BEI. Hal ini sejalan dengan hasil penelitian yang dilakukan oleh Azhari (2016), yang menyatakan bahwa total asset turnover tidak berpengaruh terhadap harga saham.

\section{c. Pengaruh Retun on Invesment Terhadap Harga Saham \\ Return on invesment pada $t_{\text {hit }}$ sebesar} 1.717, sedangkan $t_{\text {tab }}$ sebersar 1.65508 atau $\mathrm{t}_{\text {hit }}>\mathrm{t}_{\mathrm{tab}}$ dengan kata lain $1.717>1.65508$, yang menunjukkan secara parsial return on invesment berpengaruh terhadap harga saham dan tidak signifikan pada perusahaan manufaktur yang terdaftar di BEI. Hal ini sesuai dengan hasil penelitian yang dilakukan oleh Priatinah (2012) yang hasilnya secara parsial return on investment berpengaruh terhadap harga saham.

\section{d. Pengaruh Earning Per Share Terhadap Harga Saham \\ Earning per share pada thit sebesar} 9.232, sedangkan $t_{\text {tab }}$ sebersar 1.65508 atau $\mathrm{t}_{\text {hit }}>\mathrm{t}_{\mathrm{tab}}$ dengan kata lain 9.232 >1.65508, yang menunjukkan secara parsial Earning per share berpengaruh signifikan terhadap harga saham pada perusahaan manufaktur yang terdaftar di BEI. Hal ini sesuai dengan hasil penelitian yang dilakukan oleh Priatinah (2012) yang hasilnya secara parsial earning per share berpengaruh terhadap harga saham. 


\section{KESIMPULAN DAN SARAN}

\section{a. Kesimpulan}

Kesimpulan yang dapat disimpulkan pada penelitian ini adalah:

Kesimpulan yang dapat dihasilkan dari penelitian ini adalah secara simultan pertumbuhan perusahaan, total asset turnover, return on investment dan earning per share berpengaruh terhadap harga saham pada perusahaan manufaktur di BEI, sedangkan secara parsial variabel yang berpengaruh terhadap harga saham adalah earning per share.

\section{b. Saran}

Saran yang dapat dilakukan oleh peneliti yaitu sebelum investor menanamkan dananya sebaiknya dan seyogyanya lebih memperhatikan beberapa faktor seperti pertumbuhan perusahaan, total asset turnover, return on investment dan earning per share dan juga faktorfaktor lainnya, peneliti selanjutnya dapat diharapkan dapat menambahkan periode waktu penelitian agar didapatkan hasil yang lebih akurat dari hasil yang sekarang.

\section{DAFTAR PUSTAKA}

Azhari Diko Fitriansyah, Sri Mangesti Rahayu dan Zahroh Z.A, 2016. Pengaruh ROE, DER, TATO, Dan PER Terhadap Harga Saham Perusahaan Properti Dan Real Estate Yang Go Publik Di Bursa Efek Indonesia. Jurnal Admnistrasi dan Bisnis (JAB), Volume 32, No. 2, Maret.

Brigham Eugene F. and Joel F. Houston. 2006. Dasar- Dasar Manajemen Keuangan. Edisi 10 Buku 2. Salemba Empat, Jakarta.

Husnan Suda dan Enny Pudjiastuti, 2004. Manajemen Keuangan. Edisi Lima, Penerbit UPPAMP YKPN, Yogyakarta.
Jogiyanto H.M, 2000. Teori Portofolio dan Analisis Investasi. Penerbit BPFE, Yogyakarta.

Muhardi Werner, 2013. Analisis Laporan Keuangan, Proyeksi dan Valuasi Saham. Penerbit Salemba Empat, Jakarta.

Priatinah Denies dan Prabandaru Adhe Kusuma, 2012. Pengaruh Return on Invesment (ROI), Earning Per Share (EPS), dan Dividen Per Share (DPS) Terhadap Harga Saham Perusahaan Pertambangan Yang Terdaftar Di Bursa Efek Indonesia (BEI) Periode 2008 - 2010. Jurnal Nominal, Volume I, No I.

Rachmad Alwi Abdul dan Sutrisno, 2013. Analisis Pengaruh Faktor-Faktor Fundamental Terhadap Harga Saham Perusahaan Manufaktur. Procedding Seminar Nasional dan Call Papers Sancal, Surakarta, 23 Maret.

Tan Syamsurijal, Agus Syarif dan Delfira Ariza, 2014. Analisis FaktorFaktor yang Mempengaruhi Harga Saham Pada Industri Trasportation Services Di Bursa Efek Indonesia Tahun 2009 - 2012. Jurnal Dinamika Manajemen, Volume 2, No. 2, April-Juni. 